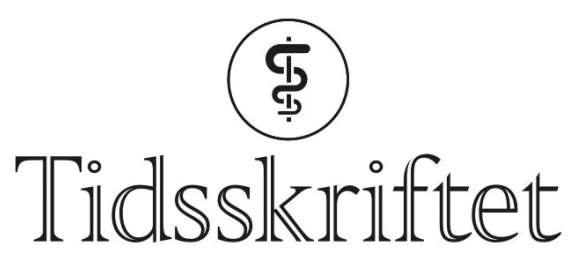

DEN NORSKE LEGEFORENING

\title{
Allergologisk kompetanse er viktig
}

\author{
KOMMENTAR \\ MARIE ALNAES \\ mariealnaes1@gmail.com \\ Marie Alnæs er overlege ved Seksjon for klinisk spesialallergologi, Yrkesmedisinsk avdeling, \\ Haukeland universitetssjukehus.
}

TORGEIR STORAAS

EVA STYLIANOU

ANDERS TØNDELL

MARTIN SøRENSEN

Ingen av forfatterne har oppgitt noen interessekonflikter.

Vi takker forfatterne A. Østrem og T. Øien for deres innspill om muligheten for å behandle allergi med immunterapi (1). Vi er enige i at mange kolleger i allmennmedisin trygt kan tilby sublingual allergen immunterapi (SLIT) og at dette vil øke tilgjengeligheten av behandlingen. Vi har allikevel noen kommentarer til innlegget.

Sublingual allergen immunterapi mot bjørk- og gresspollenallergi kan forskrives av alle leger, men vår erfaring på de regionale sentrene for astma, allergi og annen overfølsomhet (RAAO) er at det er viktig at den som forskriver både har kunnskap og interesse for behandlingen.

Det understrekes at det er et krav for oppstart at pasienten har hatt moderat til alvorlig sesongavhengig gress/bjørkepollenindusert rhinitt eller konjunktivitt i minst to år, og at optimal basismedikasjon (antihistaminer og nasale steroider) ikke har nok effekt, eller ikke kan brukes av tungtveiende medisinske grunner. Dette er poengtert i teksten for vilkår om blå resept for behandlingen (2,, 3$)$. Astma må være velregulert. Behandlingen skal startes utenom pollensesong og videre kontraindikasjoner som beskrevet i veilederen må også vurderes før oppstart.

Norsk praktisk veileder i allergivaksinasjon er tilgjengelig gratis på legeforeningens sider (4.), og alle som behandler pasienter med allergen immunterapi bør være godt kjent med innholdet. Det er viktig at den som skriver ut behandlingen informerer grundig om at 
lokal hevelse og kløe i munnhulen er vanlig i starten, og vurderer behov for antihistaminer for å øke toleransen for behandlingen. Vi ser stadig pasienter som har fått dårlig informasjon, blitt redd og seponert behandlingen.

For allergen immunterapi mot husstøvmiddallergi er det krav for blåresept at behandlingen startes av spesialist med allergologisk kompetanse (5). Ved vurdering bare ut fra IgE nivå og prikktest vil mange kunne bli overbehandlet for husstøvmiddsensibilisering. Det foreligger bred sensibilisering for husstøvmidd i befolkningen, men de færreste har behandlingskrevende allergi. Vi foreslår derfor at sublingual allergen immunterapi mot husstøvmidd vanligvis startes av spesialist med allergologisk kompetanse.

Kompetanseområdet allergologi er tilgjengelig for spesialister i allmennmedisin, og vi $\emptyset n$ nker oss flere kollegaer i allmennmedisin med denne utdannelsen. I tillegg finnes det emnekurs i allergologi spesielt rettet mot allmennleger. Vi anbefaler også samtidig nettkurs i praktisk anafylaksibehandling (므), som er et gratis nettkurs for alt helsepersonell, da oppstart sublingual allergen immunterapi sjeldne ganger kan utløse anafylaksi.

Den norske praktiske veilederen i allergen immunterapi er for tiden under revisjon, og vi vil også invitere Norsk forening for allmennmedisin inn i revisjonsarbeidet.

\section{LITTERATUR}

1. Østrem A, Øien T. Fastlegen kan behandle allergi med immunterapi. Tidsskr Nor Legeforen 2021; 141. doi: 10.4045/tidsskr.21.0053. [PubMed][CrossRef]

2. Felleskatalogen. Grazak. https://www.felleskatalogen.no/medisin/grazax-alk-559732 Lest 24.03.2021

3. Felleskatalogen. Itulazax. https://www.felleskatalogen.no/medisin/itulazax-alk-666655\#pakninger Lest 24.03.2021

4. Den norske legeforening. Praktisk veileder i allergivaksinasjon (2011)

https://www.legeforeningen.no/om-oss/publikasjoner/veiledere/praktisk-veileder-i-

allergivaksinasjon-2011/ Lest 24.03.2021

5. Felleskatalogen. Acarizax. https://www.felleskatalogen.no/medisin/acarizax-alk-614696 Lest 24.03.2021

6. Praktisk anafylaksibehandling. https://kursbygger.ihelse.net/?startcourseid $=17$ \&tracking= Lest 24.03.2021

Publisert: 25. mai 2021. Tidsskr Nor Legeforen. DOI:10.4045/tidsskr.21.0346

(C) Tidsskrift for Den norske legeforening 2023. Lastet ned fra tidsskriftet.no 26. april 2023. 